\title{
The Interplay between Insurers' Financial and Asset Risks during the Crisis of 2007-2009
}

\author{
Etti Baranoff ${ }^{\mathrm{a}}$ and Thomas W. Sager ${ }^{\mathrm{b}}$ \\ ${ }^{a}$ Virginia Commonwealth University, Snead Hall, 301 West Main street, Richmond, VA 23284, U.S. \\ ${ }^{\mathrm{b}}$ Department of Information, Risk, and Operations Management, The University of Texas at Austin, \\ CBA 5.202, Austin, Texas 78712-1175, U.S.
}

In this study we compare the interplay between capital and asset risks before and during the 2007-2009 financial crisis for the U.S. life and health insurance industries partitioned into segments by product specialisation, size and governance. The results show substantial intra-industry variation in the partial elasticity of capital with respect to asset risk, as well as significant impact of the crisis. Segment variation was driven by product focus. Most notable is the greater impact of the crisis on the U.S. insurers specialising in annuities (least risky product) than on specialists in health lines (riskiest product). During the crisis, the elasticity between asset risk and capital declined for all segments indicating that insurers' operation may have shifted from offsetting risk to seeking risk.

The Geneva Papers (2011) 36, 348-379. doi:10.1057/gpp.2011.15

Keywords: asset risk; financial risk; product risk; capital structure; 2007-2009 crisis

\section{Introduction}

In the wake of the financial crisis of 2007-2009, pressure mounted for reform of the U.S. and global economic systems. Widely viewed as responsible for the economic crisis, the financial sector lay at the crosshairs of calls for increased regulation and monitoring. Some U.S. reforms were implemented with the enactment of the "Dodd-Frank Wall Street Reform and Consumer Protection Act" in July 2010. ${ }^{1}$ Although the banking subsector of the financial industry received the most attention in the preceding public debate, as well as in the provisions of the Act, insurance was not left out. Among other provisions, the Act created the Federal Insurance Office (FIO) with responsibility to monitor the insurance industry for systemic risks. At the global level, the G-20 created the Financial Stability Board (FSB) to create prudential regulation of the global financial sector and designate Systemically Important Financial Institutions (SIFIs). The FSB asked the International Association of Insurance Supervisors (IAIS) to provide indicators to identify SIFIs in insurance. There is currently debate over the issue of whether insurers can originate systemic risk through their insurance operations. ${ }^{2}$

\footnotetext{
${ }^{1} 2010$ also witnessed enactment of another substantial piece of legislation with potential for significant impact upon the insurance industry. The Patient Protection and Affordable Care Act (PPACA) mandated a number of health insurance reforms and implemented further Federal regulation of health insurers.

${ }^{2}$ For example, see the report "An Analysis of the AIG Case-Understanding Systemic Risk and its Relation to Insurance" 2011 by Etti Baranoff, The Geneva Association at: www.genevaassociation.org.
} 
In this paper, we examine how the financial crisis affected the way insurers in both the life and health insurance industries in the U.S. manage their capital and asset risks within the context of their enterprise risks. We use the laboratory created during the financial crisis of 2007-2009 to provide insights into intra-industry variation in the risk-taking behaviour of life and health insurers. Among other uses, the results could inform the work of both State and Federal insurance regulators of these industries as they strive to implement the recent reform legislation and to prevent or ameliorate potential future crises.

In our quantitative analysis, we examine the elasticity of insurer capital during and immediately preceding the crisis, especially in relation to asset risk, but also within the context of the other major risks to which insurers are subject. We are especially interested in intra-industry differences in the capital-risk interrelationship. To facilitate analysis of the latter, we partition these industries into segments by predominant business focus into health and accident, life, annuity, reinsurance, and combination segments. In addition, we examine partitions based upon other criteria, such as size and organisational form.

Strikingly, we find that during the crisis all segments moved uniformly towards lower capital elasticities with respect to asset risk. ${ }^{3}$ The capital elasticities of all segments were reduced by factors of three to five. When the capital/risk relationship becomes inelastic, insurers may lose their ability to increase capital in response to increased asset risk. A more alarming interpretation of a move towards capital/risk inelasticity is that insurer incentives may shift from offsetting risk to seeking risk, as in a "gofor-broke" mode. We examine evidence for the finite-risk hypothesis (that firms limit total risk by offsetting increased risk in one area by decreased risk in another) vis-à-vis the excessive risk hypothesis (that firms sometimes seek increased total risk). We find that all segments remained within the finite-risk regime, but all moved towards the excessive risk realm. The annuities segment had by far the largest absolute movement. These intra-industry segment differences can be tied to the different business foci of the segments. Findings such as these, which not only point out industry-wide sensitivities to risk, but also differentiate higher and lower sensitivities within the industry, may help the newly created FIO and state insurance regulators to understand these important industries better.

We use the rich financial data of both U.S. life insurers and health insurers to create proxies of insurers' enterprise risks. On the basis of popular and academic literature, ${ }^{4}$ we focus on four broad categories of insurers' enterprise risks: product risk, asset risk, financial risk (capital structure) and operational risk. The first part of our analysis presents a simple descriptive discussion of univariate changes in our risk proxies from 2006, just before the crisis, to 2008, in the midst of the crisis. The second part of our analysis is a simultaneous equations model for the interplay between financial risk (in the form of capital) and asset risk. In the model, capital and asset risk are treated as endogenously interacting, with each modelled by a separate structural equation. In the model, product risk and operational risk are treated as exogenous or predetermined.

\footnotetext{
${ }^{3}$ Except for reinsurance, which has a small sample size and lacks statistical significance in 2006.

${ }^{4}$ For example, see Gleason (2000).
} 
The theoretical justification for treating product risk as predetermined is the business strategy hypothesis, which views the choice of business focus (or product line) to be logically prior to other choices, such as the choice of capital structure and asset portfolio composition. In addition, we view capital and asset risk a priori as much more likely to have been affected by the financial crisis than product or operational risks, as usually conceived. In fact, we argue that product and operational risks should have remained rather stable over the study period. There are three reasons for stability: (1) the crisis impacted asset and financial risks much more strongly than product and operational risk; (2) product risk stability is consistent with the fundamental role of the product in the business strategy hypothesis; and, (3) the fundamental risks of insurance products derived from mortality, life expectancies and morbidity were not affected by the crisis. ${ }^{5}$ The model is run separately for each group of insurers in our industry segments (annuity insurers, life, health, reinsurance; small insurers, large; stock and non-stock insurers). Since we expected significant intraindustry heterogeneity, we omitted construction of a model for the combination of all segments of the life and health industries. However, we did run the models for the health industry separately from the life industry.

As a basis for our models, we reviewed selected prior capital structure studies for non-financial firms, ${ }^{6}$ as well as capital/risk studies for banks, ${ }^{7}$ for the property/ casualty insurance industry, ${ }^{8}$ and for the life insurance industry. ${ }^{9}$ Although capital structure studies of non-financial companies focus on capital and debt, corresponding studies for financial institutions must be refocused. Insurers, in particular, have little traditional debt. Insurers collect and invest premiums in various assets that are held in the form of reserves to pay future claims. Ultimately, the reserves will be repaid to policy-holders collectively in the form of future claims, just as bonds of a non-financial firm will be repaid to investors individually upon maturity. For insurers, these reserves are the closest analogue to the debt of non-financial firms. The quality and safety of the assets held for future claims is crucially important to the firm, the policy-holders and regulators. If the assets are risky and of low quality, an insurer may need to add prudently to capital if it wishes to limit its overall risk. Theories of insurer behaviour that predict firms will balance an increase in risk in one area (like acquiring more risky assets) with a reduction in risk in another (like increasing capital) we call collectively the finite risk hypothesis. Theories that predict that firms will sometimes seek to increase overall firm risk we call collectively the excessive risk hypothesis. One of the objectives of our study is to determine the position of the industry segments on the spectrum of finite risk to excessive risk. The above discussion suggests that the focus on capital and debt of capital structure studies for non-financial firms can be shifted justifiably to a refocus on capital and asset risk for financial firms.

\footnotetext{
${ }^{5}$ There are additional risks associated with certain life and annuity products such as guarantees for minimal returns. These risks are part of asset risk instead of product risk.

${ }^{6}$ For example, Titman and Wessels (1988); Harris and Raviv (1991), Shyam-Sunder and Myers (1999), Hovakimian et al. (2001), Hovakimian et al. (2004) and Flannery and Rangan (2006).

${ }^{7}$ Shrieves and Dahl (1992).

${ }^{8}$ Cummins and Sommer (1996).

${ }^{9}$ Baranoff and Sager (2002 and 2003).
} 
As noted, a key part of our study is the segmentation of the life and health industries into subgroups. MacKay and Phillips ${ }^{10}$ show that intra-industry variation is important in explaining financial and real decisions. The insurance industry is heterogeneous, with insurers specialising in very different types of products-life, annuities, health and reinsurance. The capital/risk studies of Baranoff and Sager ${ }^{9}$ in insurance, as well as a myriad of non-financial capital structure studies, have recognised the importance of the product/input. ${ }^{11,12}$ All these studies regard the product/input as an important determinant in capital structure studies, but have not incorporated the "business strategy" foundation to drive segmentation. In our work, we accord product an even greater role as a foundation to many other decisions. Most important is the proposition that a difference in product specialty leads to a difference in levels of risk undertakings.

A glance at a few statistics reveals the importance of the life and health insurance industries. In 2008, the life industry held assets in the amount of US\$4.6 trillion, liabilities of US\$4.3 trillion and collected premium income of US\$759 billion. By contrast, the health insurance industry held US\$151 billion in assets, US\$72 billion in liabilities and collected premium income of US\$346 billion. From these figures, it is evident that the capital to asset ratio of the health insurance industry must be much greater than that of the life insurance industry. This disparity can be explained by the nature of the two industries. Overall, many insurers maintain large asset portfolios, which include Great Recession culprits like mortgage-backed securities (MBS), real estate and mortgages, as well as safer bonds. But life insurers, especially the annuity segment, hold much larger portfolios than do health insurers - a difference driven by the differences in their product specialisations. Health insurers face frequent, irregular short-term claims, for which they need large amounts of liquid assets and therefore concentrate their portfolios on cash and cash-equivalents. On the other hand, annuity insurers face predictable, regular long-term payouts and concentrate their portfolios on long-term investments. The nature of the predominant business of an insurer strongly mediates its risk profile and financial risk vs. asset risk.

In the next section of the paper, we discuss our hypotheses in the context of the underlying theory. This includes additional discussion of our repositioning of the debt/ equity focus of capital structure studies of non-financial firms to a capital/asset risk focus for insurers. This is followed by the data section. The subsequent section is the methodology and the penultimate section includes the results of our models. The paper concludes with a summary.

\section{Theoretical foundation}

\section{Enterprise risk}

The subject of managing the firm's holistic, enterprise-wide risks has found a major audience in the past two decades. The terrorist attack of 11 September 2001 ratcheted

\footnotetext{
${ }^{10}$ MacKay and Phillips (2005).

${ }^{11}$ Faulkender and Petersen (2006).

${ }^{12}$ Harvey et al. (2004); Leary and Roberts (2005); Miao (2005); and Kayhan and Titman (2007).
} 
up the interest. Enterprise risk management (ERM) activities are now part of the analysis of firms by rating organisations. ERM focuses on both pure risks and speculative risks - potential losses and gains with the main objectives of minimising risks of failure while maximising value. ${ }^{13,14}$ For insurers, the literature and practice recognise four main categories of risks: asset risk, product risk, financial risk and operational risk.

\section{Business strategy hypothesis}

Within the spectrum of enterprise risks, product risk may be assigned a priority position. For a firm, the choice of product is a fundamental decision that may be viewed as logically prior to other important decisions, like capital structure, asset investments, etc. Therefore, the product choice may affect, or even drive, many other decisions. The notion of product choice as a driver of other decisions is rooted in transaction cost economics theory (TCE), first introduced by the Noble Prize laureate, Ronald Coase in 1937, and further developed by the 2009 Nobel Prize laureate, Oliver Williamson. Williamson ${ }^{15}$ views major firm decisions as flowing from the nature of the product and the contracts associated with their transactions. For insurers, Regan and Tzeng ${ }^{16}$ adopt a similar view. This view has been called the business strategy hypothesis. Adopting the viewpoint of those authors, we therefore treat the business strategy/product focus as a predetermined ${ }^{17}$ variable for the capital structure and asset risk decisions. That is, we pick up the action after the product choice has been made, but before the capital and asset risk decisions have been (jointly) made. In capital structure studies of non-financial firms, the product/input impact on leverage is also well-documented. The Harris and Raviv ${ }^{18}$ survey notes a few studies arguing that leverage increases with the uniqueness of products. More recently, Faulkender and Petersen $^{11}$ use the ratio of research and development expenses to sales "to proxy for the uniqueness of the firm's products as well as the uniqueness (and the lack of liquidity) of the firm's collateral". Other recent studies noting the importance of product/input include Harvey et al., Leary and Roberts, Miao, and Kayhan and Titman. $^{12}$

\footnotetext{
13 Santomero and Babbel (1997).

${ }^{14}$ Babbel and Merrill (2005).

15 Williamson (1985 and 1988).

16 Regan and Tzeng (1999).

17 The distinction between an exogenous and a predetermined variable is that the value of an exogenous variable is, in fact, determined externally to the system under study, whereas the value of a predetermined variable is treated as though it is determined externally for the purpose of the study. (However, their mathematical treatment is the same.) For example, an indicator variable for a year would be clearly exogenous. The firm's business strategy just as clearly is not exogenous in this sense, since it is the firm that decides its own strategy. However, the business-strategy hypothesis views the capital and asset risk decisions under study in this paper as logical consequences of the choice of what business to be in, even though in a temporal sense, all of these decisions may be made almost simultaneously. Therefore, in this paper, we pick up the analysis of the firm after and conditioned upon its business-strategy decision. We thus treat the business-strategy as predetermined, but not exogenous.

${ }^{18}$ Harris and Raviv (1991).
} 
In our approach to product risk, we partition the insurance industry into segments by assigning each insurer to precisely one of the major product types (health, annuities, life, reinsurance), according to the predominant type in the insurer's premium mix (or to a "combination" segment if no one type clearly predominates), per Baranoff et al. ${ }^{19}$ The theoretical justification for partitioning the industry - and product risk - into four separate types is also TCE, which emphasises the differential risk characteristics of the various product types in terms of the degree of completeness or incompleteness and relational nature of their insurance contracts. Implicit in this partitioning is a definition of product risk: We define the product risk of each insurer to be its set of exposures to the four major types of insurance products. Given this definition, we find it natural to measure an insurer's product risk by the vector of proportions of premiums written in the four major types. So an insurer has a product risk for each of the four major types of insurance products, and the vector of those proportions is a product risk profile for the insurer.

Of course, other definitions are possible. However, defining product risk in terms of exposures has some advantages over defining product risk in terms of outcomes like lapse rates, loss ratios, etc. First, exposure to a product type embodies all potential outcomes, whatever they may be, that are associated with that product type, without needing to specify or measure them. If an insurer specialises in annuities, it will experience substantial mortality, longevity, lapse, loss and all other annuity-associated outcomes at the level inherent to the annuity business, as modified by insurer skill and aggravating factors. Second, exposure is ex ante and so may be closer in spirit to the common understanding of "risk" than an ex post outcome metric. Third, we have exposure data for all insurers; but we do not have loss ratios or lapse rates for all product types. Fourth, defining product risk as exposure does not imply a particular ranking of the types of product risk. All that we require to justify partitioning the risks is that TCE declare that the four types are substantially different. We can run the models in this paper just as we have, without needing to rank the risks. However, as will be seen, our results will make more sense if we can interpret a given level of annuity product risk (for example) as less risky than the same level of health product risk.

In seeking a possible rationale for ranking the product risk types, we again appeal to TCE, which provided the theoretical foundation for the business strategy hypothesis as well as for our partitioning of product risk by product type. We ask if TCE provides a perspective by which we can also order the risk types. Our reading of TCE theory suggests that TCE would rank the order of product types in increasing uncertainty of outcome as follows: annuities, then life insurance, then health and accident insurance and reinsurance? ${ }^{20}$ As reflected in prior life insurance literature, TCE maintains that the greater the uncertainty regarding the outcome of an insurance product, the greater the impetus for financing via capital (a risk mitigating approach). An annuity contract is more complete and less ambiguous than other products in terms of the promise to the policy-holder. On the other hand, health insurance and reinsurance are considered

\footnotetext{
${ }^{19}$ Baranoff et al. (1999).

${ }^{20}$ TCE considers reinsurance to be the most incomplete because reinsurers assume risks that may not be well underwritten. Thus they have less control over the outcome of the contracts.
} 
quite risky for insurers because these contracts are incomplete and relational per Williamson. ${ }^{21}$ The promise in the contract is subject to interpretation as states of the world change-for example, changes due to medical technology innovation and legislative reforms.

\section{Capital structure of insurers}

Following the choice of product, the firm faces the financing decision and its accompanying risks. As suggested in the Introduction section, we regard the financing decision for insurers as a joint decision about capital and asset risk, viewed as locked in a mutual interplay. An insurer collects premiums and converts them into invested assets. These assets are used to pay future claims. The holding periods or maturities of the invested premiums are coordinated to match the timeline of expected claims payments to policy-holders, a management procedure known as asset/liability matching. The policy-holders can be considered analogous to debt holders in non-financial firms. The debt holders regard the credit rating of the firm and its debt as critical. The cost of capital and the cost of debt depend upon the riskiness of the firm debt. Thus, the risk of firm debt impacts the capital structure and vice versa. Correspondingly, for insurers the quality of the assets in which the premiums are invested affects the capital structure decision. So the equity/debt decision in non-financial firms shifts to the capital/asset risk decision for insurers.

With stakeholders focused on the insurer's assets, the insurer must examine its asset portfolio from two perspectives. First, from the standpoint of customers, will the quality of the asset portfolio persuade them to purchase policies? Insurance customers want high probability of claims payments and low risk of insolvency. Second, will insurance regulators be satisfied with the safety of invested assets? Regulators also want low risk of insolvency and apply risk-based capital formulae and many other criteria to judge solvency.

Thus, it is apparent that asset risk is important for insurers and that asset risk and capital decisions are interconnected, as the equity/debt decisions are interconnected for non-financial firms. Ceteris paribus, an increase in capital reduces total firm risk and thus the relative level of asset risk; a decrease in capital increases total firm risk. Thus, it is reasonable that an insurer would set its capital structure jointly for both capital and asset risk.

\section{Theories of life and health insurers' enterprise risk behaviour}

As explained briefly in the Introduction section, the literature entertains two opposing hypotheses about the relationship between capital and risk for insurers. One set of theories predicts that the relationship between capital and asset risk is positive. If an insurer acts to limit its overall risk, then maintaining a low level of capital (high financial risk) would constrain it to pursue a conservative investment policy (low asset risk), and vice versa. In this scenario, we would expect a positive correlation between

\footnotetext{
${ }^{21}$ Williamson (1985).
} 
capital and asset risk, given other enterprise risks. Because such theories imply that firms balance greater risk in one activity with lower risk in another, we refer to these theories collectively as the finite risk hypothesis. They include agency theory, ${ }^{22}$ transactions cost economics theory, ${ }^{15,23}$ bankruptcy and regulatory cost, and complete markets. For example see Cummins and Sommer ${ }^{8}$ for the property/casualty industry, Berger $^{24}$ for the banking industry and Baranoff and Sager $^{9}$ for the life insurance industry.

On the other hand, if an insurer does not act to limit its overall risk, then there may be situations in which the insurer seeks to increase its overall risk. Thus, maintaining a low level of capital (high financial risk) might lead it to pursue an aggressive investment policy (high asset risk), and vice versa. In this scenario, we would expect a negative correlation between capital and asset risk. In the literature, some theories have predicted this outcome. Because they imply that greater risk in one activity may lead to greater risk in another, we refer to these theories collectively as the excessive risk hypothesis. The risk subsidy of guaranty funds provides one possible mechanism for the operation of this moral hazard. Others include asymmetric information and signalling - see Cummins, Berger et al. and Downs and Sommer. ${ }^{25}$ Babbel and Merrill ${ }^{14}$ provide a model of firm value maximisation that explains numerous circumstances in which insurers have been observed to seek excessive risk.

During the financial crisis of 2007-2009, life and health insurers' investment portfolios were hard hit: values of stocks, bonds and real estate decreased and volatility of the returns increased substantially. Therefore, we expect that asset risk increased during the crisis. Per Baranoff and Sager, ${ }^{26}$ a significant proportion of insurers' bond portfolios had become MBS by the time of the crisis. Part of the expected increase in asset risk should be attributable to the effect of these securities. ${ }^{27}$ Baranoff and Sager ${ }^{26}$ also found that in the run-up to the financial crisis, life insurers behaved as though the acquisition of MBS actually reduced insurer risk. Since asset risk and financial risk are interdependent, we therefore expect insurers to have accumulated capital during the crisis if they follow finite risk and to have shed capital if they follow excessive risk, ceteris paribus. However, insurers may have had difficulty getting access to capital during the crisis. Thus, even insurers that follow finite risk may have been nudged towards excessive risk by circumstances.

\section{Hypotheses regarding the risk behaviour of segments of life and health insurers}

In this section we combine the business strategy hypothesis with the finite risk hypothesis to create the expectations for the interrelationships between the capital and asset risk across the different segments of the life and health insurers.

\footnotetext{
22 Starting with Jensen and Meckling (1976).

${ }^{23}$ Coase (1937).

24 Berger (1995).

${ }^{25}$ Cummins (1988), Berger et al. (1995) and Downs and Sommer (1999).

${ }^{26}$ Baranoff and Sager (2009).

${ }^{27}$ To account for the asset risk derived from MBS, we added exposure to MBS as an additional predictor.
} 
Table 1 shows our expectations for the coefficient of asset risk in our capital equation model (see Eq. (1) in Methodology section) in the various segments. For Table 1, we adopt the working hypothesis that the life and health insurance industries operate under finite risk. Our expectations for the various industry segments are driven by differences among the segments in product risk, as interpreted by the business strategy hypothesis. We hypothesise that under pre-crisis conditions, the coefficient of asset risk will be positive for all segments - reflecting the prevalence of the finite risk regime. We expect that segments with relatively small asset portfolios will have low asset risk coefficients. It would be natural under finite risk for firms in such segments to use capital to balance other risks than their relatively low asset risk. Segments with relatively large asset portfolios should have a much more elastic relationship between capital and asset risk, since their assets would be relatively more important. During the crisis, in 2008, we expect finite risk to be under pressure, as asset portfolio volatility increases and sources of capital dry up. This should be reflected in lower asset risk coefficients - possibly even negative coefficients if segments switch from finite risk to excessive risk. We expect the deterioration in coefficients to be more pronounced in segments that had relatively larger asset portfolios before the crisis, since those segments would have been hit harder by the crisis.

\section{Data}

In this study, we use U.S. life insurers' and U.S. health insurers' annual report data filed with the National Association of Insurance Commissioners (NAIC) for 2006 and 2008. Our choice of study years is motivated by our desire to compare the behaviour of insurers in the immediate pre-financial crisis (2006) to the behaviour of the same insurers at the height of the crisis (2008). We merged the data of the life and health industries and extracted common variables.

\section{Segmentation of insurers}

Next, we partitioned the merged industries into five segments by predominant product specialty: health, life, annuities, reinsurance and combination (mixture, or no specialty). An insurer was classified as a health specialist if 70 per cent or more of its premiums originated from health coverage. The 70 per cent cut-off defined the other specialty segments, as well. Insurers that remained unclassified by this method were assigned to the combination (no specialty or diversified) segment. Independently of the segmentation by specialty, we partitioned the merged health and life insurers into size segments on the basis of total assets. The large segment consists of insurers with total assets exceeding US $\$ 1,000,000,000$; the small segment consists of insurers with less than this amount of total assets. Setting the cut-off at US\$1 billion, rather than a higher figure, produces a sufficient number of large insurers to draw statistically meaningful conclusions. Finally, we segmented the merged health and life insurers by organisational form: stock and non-stock. Firm-year counts are shown in Table 2. 


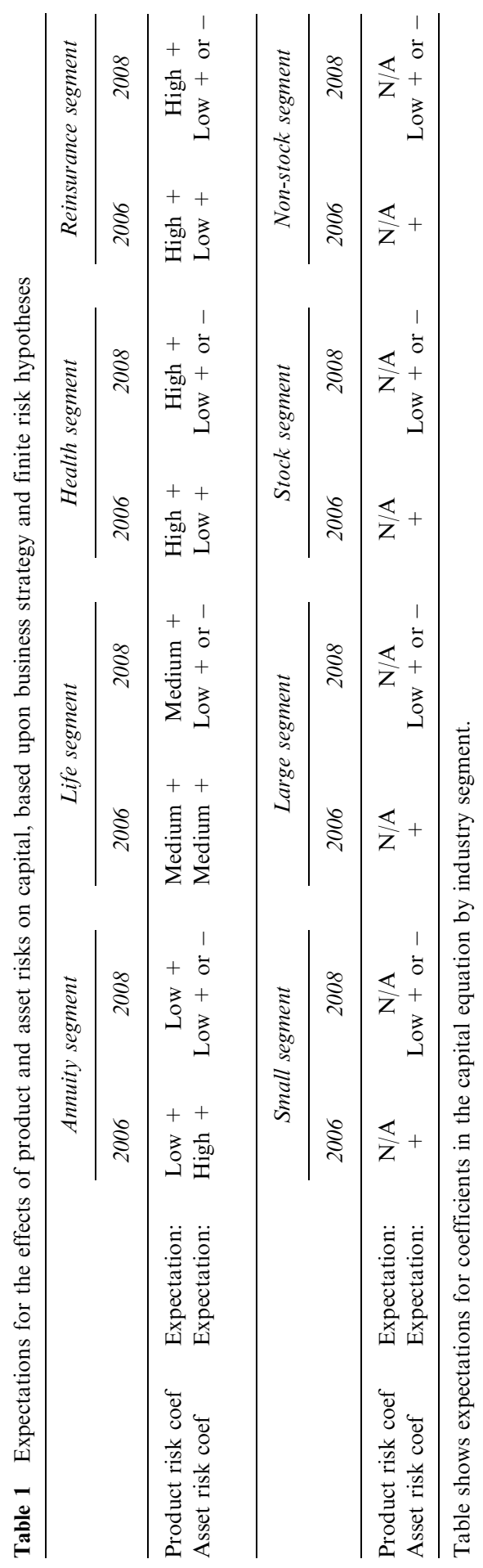


Table 2 The number of insurers in each of the life and health industries and their segments

\begin{tabular}{lcrr}
\hline \multicolumn{4}{c}{ All Health Filers and Life Filers } \\
\hline Year & Health & Life & Total \\
\hline 2006 & 874 & 870 & 1744 \\
2008 & 878 & 838 & 1716 \\
Total & 1752 & 1708 & 3460
\end{tabular}

All Health Filers and Life Filers, by product specialty segment

\begin{tabular}{lrrrrrrr}
\hline Year & Health $^{\text {a }}$ & Annuity & Combination $^{2}$ & Healt $^{\text {a }}$ & Life & Reinsur $^{\text {Total }}$ \\
\hline 2006 & 874 & 93 & 263 & 165 & 250 & 99 & 1744 \\
2008 & 878 & 94 & 218 & 159 & 232 & 86 & 1667 \\
Total & 1752 & 187 & 481 & 324 & 482 & 185 & 3411
\end{tabular}

All Health and Life Filers, by organisational form and by size

\begin{tabular}{lccccccr}
\hline \multirow{2}{*}{ Year } & \multicolumn{3}{c}{ By organisational form } & & \multicolumn{3}{c}{ By size } \\
\cline { 2 - 3 } \cline { 6 - 7 } & Stock & Non-stock & Total & & Small & Large & Total \\
\hline 2006 & 1445 & 299 & 1744 & & 1457 & 287 & 1744 \\
2008 & 1424 & 292 & 1716 & & 1449 & 267 & 1716 \\
Total & 2869 & 591 & 3460 & & 2906 & 554 & 3460 \\
\hline
\end{tabular}

${ }^{a}$ Many insurers classified as health specialists under our 70 per cent-of-premiums rule file as life insurers with the NAIC. Shown as separate groups in Table 2, these two sets of health specialists are treated as one combined group in our analysis.

\section{Homologies between capital structure models for financial firms and for non-financial firms}

To aid our development of appropriate predictors for a model of insurers' capital/risk interrelations within the enterprise risks, we first surveyed relevant studies for nonfinancial firms. Recent summary discussions of capital structure predictors for nonfinancial firms are available in Hovakimian and Tehranian, ${ }^{28}$ and Flannery and Rangan. ${ }^{29}$ We then examined capital structure studies for insurers. Discussions of determinants for insurer capital and asset risk are provided by Cummins and Sommer ${ }^{8}$ for the property/casualty insurance and Baranoff and Sager $^{9}$ for life insurance. We emerged with two lists, one for non-financial firms and one for insurers. We noted some overlap between the two lists, as well as predictors that are unique to each list. Table 3 presents our lists, with analogous predictors given in the same row (where available), together with notes on the degree of similarity or difference and/or the theoretical underpinning.

\footnotetext{
${ }^{28}$ Hovakimian and Tehranian (2004).

${ }^{29}$ Flannery and Rangan (2006).
} 
Table 3 Relevant determinants of capital structure for non-financial firms [based upon Hovakimian, Hovakimian and Tehranian (2007) and Flannery and Rangan (2006)] and for insurers [based upon Cummins and Sommer (1996) and Baranoff and Sager (2002 and 2003)]

Non-financial firms

Dependent variable: Debt ratio

Insurance firms

Dependent variables (endogenous vars): Capital ratio and asset risk

Market to book ratio of assets Idea: Future growth => limiting leverage (pecking order, agency theory for non-financial firms).

Marginal tax rate

Depreciation

Stock return (traditional volatilityof-market-returns risk measure)

Asset tangibility-fixed asset proportions In non-financial firms: more tangibility $=>$ more debt capacity.

\section{Size: Total assets or revenues}

$R \& D$ intensity

$=>$ more product risk

Uniqueness of product/input
No exact analogue in insurance data

Most insurers are not publicly traded. Available asset values are a mix between book, amortised and market values depending on the particular asset. Insurer capital is book capital; liabilities are mostly computed reserves.

$N / A$

Insurance liabilities contain very little debt. The favourable tax treatment of debt is not as applicable to capital structure of insurers.

$N / A$

Depreciation is mostly not applicable to insurance since the assets are mostly not machines for production.

Opportunity asset risk

Volatility of returns risk measure. In insurance, increased holdings of risky assets $=>$ adjustments in capital, with the effect depending upon whether the insurer operates under the finite risk paradigm (increased capital) or excessive risk paradigm (decreased capital).

\section{Size: Total assets}

Economies of scope and scale

Size: Total writings (premiums)

Economies of scope and scale

Size: Total liabilities

Insurance liabilities consist of reserves to pay claims. Liabilities and assets need to match to meet the liquidity needs of claims.

Health writings/Total writings

Increase in health ratio $=>$ more product risk

Annuity writings/Total writings

Increase in annuity ratio $=>$ less product risk

Life writings/Total writings

Increase in life ratio $=>$ less product risk

Life insurers sell a mix of health, life and annuity products. These products present very different risk characteristics. Their effects on capital depend upon whether the insurer operates under the finite risk paradigm or excessive risk paradigm. It has been argued that the riskiest specialty line is health insurance. 
Table 3 (continued)

$\begin{array}{ll}\text { Non-financial firms } & \text { Insurance firms } \\ \text { Dependent variable: Debt ratio } & \begin{array}{l}\text { Dependent variables (endogenous vars): Capital ratio } \\ \text { and asset risk }\end{array}\end{array}$

$<$ No match $>$

Risk-based capital ratio:

$100 *$ book capital/(2*authorised capital)

Applicable to regulated industries. This is a proxy for regulatory forbearance. It can also proxy franchise value.

\section{Profitability}

Retained earnings can be added to capital. The pecking order theory considers earnings to be the preferred type of financing.

$<$ No match $>$

$<$ No match $>$

$R \& D$ dummy

Proxy for sophistication

\section{Return on capital (Income/capital)}

Retained earnings can be added to capital. The pecking order theory considers earnings to be the preferred type of financing.

Organisational type $(1=$ stock, $0=$ non-stock $)$

Organisation structure: Agency theory

Indicator for member of group $(1=$ yes $)$

Organisation structure: Agency theory

Indicator for use of derivatives $(1=$ yes $)$

Proxy for sophistication and/or hedging

\section{Endogenous variables}

\section{Capital ratio}

We define the capital ratio (CAP) for an insurer as the book value of insurer capital divided by insurer total assets. In the regression models, the logarithm of CAP is used to make its distribution more nearly normal. Book capital is used instead of market capital. To be sure, market capital would be preferable since significant differences between book and market value may cause our models to misrepresent the true economic relationships that we investigate. However, most insurers are not publicly traded, so market values are not available for the vast majority of our sample. Like most researchers, we elect to live with the limitations of book capital. See Graham and Harvey, ${ }^{30}$ as well as Barclay and Morellec, ${ }^{31}$ for a defense of the use of book values.

\section{Asset risk}

Opportunity asset risk (OAR) is a volatility-of-returns based measure of asset risk. We follow Baranoff et al. ${ }^{32}$ in its calculation. OAR is calculated by first applying historical monthly returns for 16 common indices to the insurer's corresponding asset portfolio components and summing the hypothetical dollar returns from all asset classes for each month. ${ }^{33}$ This yields monthly portfolio returns for each insurer. We do

${ }^{30}$ Graham and Harvey (2001).

31 Barclay and Morellec (2006).

${ }^{32}$ Baranoff et al. (2007).

${ }^{33}$ The 16 asset classes include five classes of government bonds by maturity, two classes of municipal bonds by quality, utility bonds, four classes of corporate bonds by quality, cash and short-term investments, 
not have access to actual returns of insurers. ${ }^{34} \mathrm{We}$ also use book values of the 16 asset components. ${ }^{35}$ Our proxy represents returns that an insurer could have made by investing its asset portfolio in indices that match the insurer's asset classes. Hence, the term opportunity: The insurer had the opportunity to realise our calculated OAR returns. Then the standard deviation of the 12 monthly returns on the whole portfolio in a given calendar year is calculated to yield the raw OAR for that year. Since the raw OAR is a function of the size of the portfolio, OAR is standardised by dividing the raw figure by total invested assets. Thus, the standardised OAR represents volatility of returns in relation to size of the invested portfolio. For this study, the logarithm of the standardised OAR is used in the regression analysis. ${ }^{36}$ Applying the logarithm to OAR makes its distribution more nearly normal. In addition, use of the log form in both predictor $(\log$ OAR) and response (log CAP) in our regression model makes the coefficient of $\log$ OAR directly interpretable as an elasticity: the expected percentage responsiveness of log CAP for a 1 per cent change in log OAR.

\section{Exogenous variables}

\section{Product risks based on business-strategy variables}

In this study, we segment the combined Health and Life NAIC filers by product specialty, which is consistent with the business-strategy hypothesis. Further, we use the proportion of premiums written in annuities, life, health and reinsurance as additional business-strategy proxy variables to control for further dependence on product, even within a product specialty. For the NAIC Health filers, we define a product risk measure as the ratio of premium income deriving from comprehensive health coverage to premium income from all health products. ${ }^{37}$ Adopting the business-strategy hypothesis as a working assumption, we treat the product risk proxies as predetermined,

mortgages, real estate and stocks. The corresponding indices include yields of five U.S. Treasuries by matching maturities, Aaa and Baa state and local bond yields, A-rated utility bond yields, Aaa, Aa, A, Baa corporate bond yields, six-month U.S. T-bill rates, 30-year fixed mortgage rate, NCREIF returns and the S\&P 500 composite.

${ }^{34}$ Detailed information on each asset is available in supplementary schedules from the NAIC. The information includes amount, purchase date, purchase price, sales date, sales price and Committee on Uniform Security Identification Procedures (CUSIP) number. From all of this, actual returns could be well approximated, in principle, given the investment of sufficient time and resources. However, the exercise would be so cumbersome as not to be practicable, in our view.

${ }^{35}$ Again, it would be better to have market values of the asset components in order to map true economic relationships more faithfully. Insurers annually report their best estimate of fair market values (FMV) of bonds and stocks. We compared the FMV to book value of bonds, which constitute the lion's share of life insurers' total invested assets. For the period 2004-2008, 90 per cent of life insurers had bond FMV that varied from 91 per cent of book to 107 per cent of book. So to the extent that insurers' FMV estimates approximate market values, it appears that book values may be reasonable approximations as well.

${ }^{36}$ Thus, the formula for our asset risk measure for a given year is $\log (\mathrm{OAR})=\log \left(\operatorname{stdev}\left\{\sum_{i=1}^{16} A_{i} r_{i j} ; j=1, \ldots\right.\right.$, $12\} \div \sum_{i=1}^{16} A_{i}$ ), where $A_{i}$ is the value of the $i^{\text {th }}$ asset class in the portfolio and $r_{i j}$ is the yield on the $i^{\text {th }}$ asset class in month $j$.

${ }^{37}$ Data on the breakdown of premium income by life, annuity, health, reinsurance lines are not available for Health filers. The comprehensive health line arguably represents the riskiest reported line for Health filers. 
since both capital and asset risk decisions are considered to be logical consequences of the choice of business focus. Thus, it is expected that product risk should not vary as much as other risks, due to the priority accorded to it by the business-strategy hypothesis and the consequent dependence of other risks upon it. This rationale makes it natural to treat product risk as predetermined rather than as endogenous.

\section{Operational risks and other control variables}

Some of the variables shown in Table 3 represent operational risks. ${ }^{38}$ Other Table 3 variables are used as control variables. Among the controls is size, proxied by the logarithm of the geometric mean of total assets and total liabilities. We use the log form of predictors to reduce skewness and make their distributions more nearly normal. Among the operational risks is the force of regulatory pressure, proxied by the risk-based capital ratio (RBCratio). ${ }^{39}$ The smaller the RBCratio, the less capital coverage an insurer is deemed to have for the risks of its investments. Return on capital (RetOnCap) is also used as a control variable, since it is an important contributor to capital, per the pecking order theory. ${ }^{40}$ Because of the role that MBS are perceived to have played in the recent crisis, we computed a measure of exposure to MBS (CMO_RMO_exposure), defined as the sum of holdings of residential and commercial MBS divided by total invested assets.

Use of derivatives may be associated with risk mitigation strategies that permit lower capital. We created a zero-one indicator for use of derivatives based on the presence or absence of derivative income or holdings on the annual statement. Derivative use can be considered one of the control variables or one of the operational risks. In this study, we regard it as a control, rather than of operational risk.

In a series of papers, Mayers and $\mathrm{Smith}^{41}$ made the case that the type of organisational structure is an important determinant of insurer behaviour. We focus on stock and non-stock, and include a zero-one indicator (NTYPE-stock $=1$, nonstock $=0$ ). Non-stock types include mutual, non-profit, Blue-Cross Blue-Shield, and a few other types. We regard this indicator as a choice that stems from the choice of business product. It is part of the operational risk. Likewise membership is in an affiliated group of companies, represented by a zero-one indicator (NGROUP). Table 4 lists and defines the endogenous and exogenous variables in our study.

\section{Methodology}

The statistical methodology is driven by our working hypothesis that the business strategy drives the capital and asset risk balancing decisions, which are made together in an interrelated context. When the insurer decides which specialty product to emphasise, the insurer thereby elects a specialty segment. Decisions on capitalisation

\footnotetext{
${ }^{38}$ This paper does not use a large number of proxies for operational risks for this study, as these were not the focus of risks impacted by the forces of the financial crisis. We used operational risk proxies that are used in capital structure and capital/risk research (as shown in Table 3).

${ }^{39} \mathrm{RBCratio}=$ Authorised risk-based capital $\div$ "Market" capital $\times 50$.

${ }^{40}$ See Berger (1995); and Berger and Bonaccorsi di Patti (2006).

${ }^{41}$ Mayers and Smith (1981, 1986, 1988 and 1994).
} 
Table 4 Definitions of the variables used in the models

\begin{tabular}{|c|c|c|}
\hline & Variables & Description \\
\hline \multirow{2}{*}{$\begin{array}{l}\text { Endogenous } \\
\text { variables }\end{array}$} & CAP (Capital ratio) & Capital/Total Assets \\
\hline & OAR (Asset risk) & Opportunity Asset Risk \\
\hline Predetermined/ & Size & Geometric Mean of Total Assets and Total Liabilities \\
\hline \multirow[t]{11}{*}{ Exogenous variables } & RBCratio & Risk-based Capital Ratio \\
\hline & RetOnCap & Return on Capital $=$ Income $/$ Capital \\
\hline & NType (Stock firm?) & Stock Firm (1), Non-stock Firm (0) \\
\hline & NGroup & In Affiliated Group (1), Not in Affiliated \\
\hline & (Member aff. Group?) & Group $(0)$ \\
\hline & Use derivatives? & $1=$ yes, $0=$ no \\
\hline & MBS exposure & Commercial and residential MBS/Invested assets \\
\hline & Health exposure & Proportion of premiums from health lines \\
\hline & Life exposure & Proportion of premiums from life lines \\
\hline & Annuity exposure & Proportion of premiums from annuities \\
\hline & Reinsur exposure & Proportion of premiums from reinsurance \\
\hline
\end{tabular}

and asset risk by insurers within the same segment should share more points of similarity with each other than they do with decisions by insurers outside that segment.

For example, health insurers may be expected to experience large product risks and to share a common need for large amounts of safe, liquid short-term investments in order to fund frequent health claims. Annuity insurers may be expected to invest significantly in relatively risky long-term assets, since annuity insurers play a financial intermediation role that is similar to that of banks. The investment strategy of annuity insurers is expected to be shaped in competition with other financial intermediaries. Thus, we expect a significant degree of homogeneity within each of the health and annuity specialist segments, while we simultaneously expect significant heterogeneity between the two segments as wholes.

The segmentation of the industry into five specialty segments, therefore, naturally controls to a substantial degree for the business strategy. To control for the business strategy within the size and stock/non-stock segmentations, we explicitly introduce the proportions of premiums attributable to health, annuities, life and reinsurances lines as proxies for the business strategy explained above. We also utilise these proportions within the specialty segments as a more refined continuous-scale control than the rougher assignment of insurers to specialty categories. Since the choice of business strategy logically precedes choice of capital and asset risk, we therefore treat the business strategy proxies as predetermined and view the capital and asset risk choices as mutually dependent and endogenous.

The basic form of our structural model may therefore be expressed as two simultaneous equations:

\section{Structural Model}

$$
\text { Capital } \quad C_{t}=\beta_{0}^{C}+\beta_{A}^{C} A_{t}+\beta_{C}^{C} C_{t-1}+\beta_{1}^{C} X_{1 t}+\cdots+\beta_{k}^{C} X_{k t}+\varepsilon_{t}^{C}
$$




$$
\text { Asset risk } \quad A_{t}=\beta_{0}^{A}+\beta_{C}^{A} C_{t}+\beta_{A}^{A} A_{t-1}+\beta_{1}^{A} X_{1 t}+\cdots+\beta_{k}^{A} X_{k t}+\varepsilon_{t}^{A}
$$

in which $C_{t}$ and $A_{t}$ are the endogenous capital-to-asset ratio and asset risk measures for year $t, C_{t-1}$ and $A_{t-1}$ are their values for the preceding (lag) year, and $X_{1 t}, \ldots, X_{k t}$ represent other potential predictors (exogenous and predetermined variables). Lagged dependent variables are often useful as predictors in order to capture implicitly a host of factors not explicitly listed among $X_{1 t}, \ldots, X_{k t}$. Modelling experts may recognise Eqs (1) and (2) as "unwound" versions of the partial-adjustment model. The partialadjustment model is often used to investigate firms' putative targeting of unobservable capital and risk goals. This observation may provide additional motivation for the form of our structural model, although the pursuit of targeting implications would be tangential to our objective in the current study.

The presence of endogenous variables as predictors on the right-hand side of Eqs (1) and (2) invalidates ordinary least squares (OLS) as an estimation method. Use of OLS here would produce coefficient estimates that are biased and inconsistent. Instead, we employ two-stage least squares. In the first-stage, reduced-form, estimates of $C$ and $A$ are obtained by separate OLS regressions of $C$ and $A$ on the predetermined and exogenous predictors. The predicted values of $C$ and $A$ from the first stage regression are called instruments. The instruments are then substituted for the values of $C_{t}$ and $A_{t}$ on the right-hand side of Eqs (1) and (2). In the second stage, OLS regressions of Eqs (1) and (2), with the instruments replacing $C_{t}$ and $A_{t}$ on the right-hand side, provide coefficient estimates.

At first blush, the two-stage process sounds perverse. The actual values of $C_{t}$ and $A_{t}$ in the right-hand side are replaced by estimates of their values, which are necessarily inexact since they are estimates. Thus, the instrument is not as interpretable as the actual values would be. However, use of the instruments avoids the problems of bias and inconsistency that invalidate straightforward OLS as an estimation method. Moreover, like all predictors, the instrument is interpreted via its coefficient. In that role it is superior to the original variable. In large samples, the coefficient of the instrument is closer to the true coefficient than the coefficient of the original variable is, even if the instrument poorly reproduces the original variable. The model enjoys the usual properties of two-stage simultaneous estimation procedures: Coefficient estimators are consistent and asymptotically normal, but not efficient. The better the instruments reproduce $C_{t}$ and $A_{t}$, the more efficient the procedure. In most of our segments, the instruments are quite good at reproducing $C_{t}$ and $A_{t}$.

\section{Results}

Basic comparisons between 2006 and 2008 by segment

Comparisons of 2006 with 2008 for selected key variables are shown in Tables 5, 6 and 7 by segments. Medians are shown for all variables except that the mean is shown for the use of derivatives. ${ }^{42}$ Comparisons for other variables of interest were computed but

\footnotetext{
42 The mean of a zero-one dummy variable is the proportion of one's in the sample.
} 


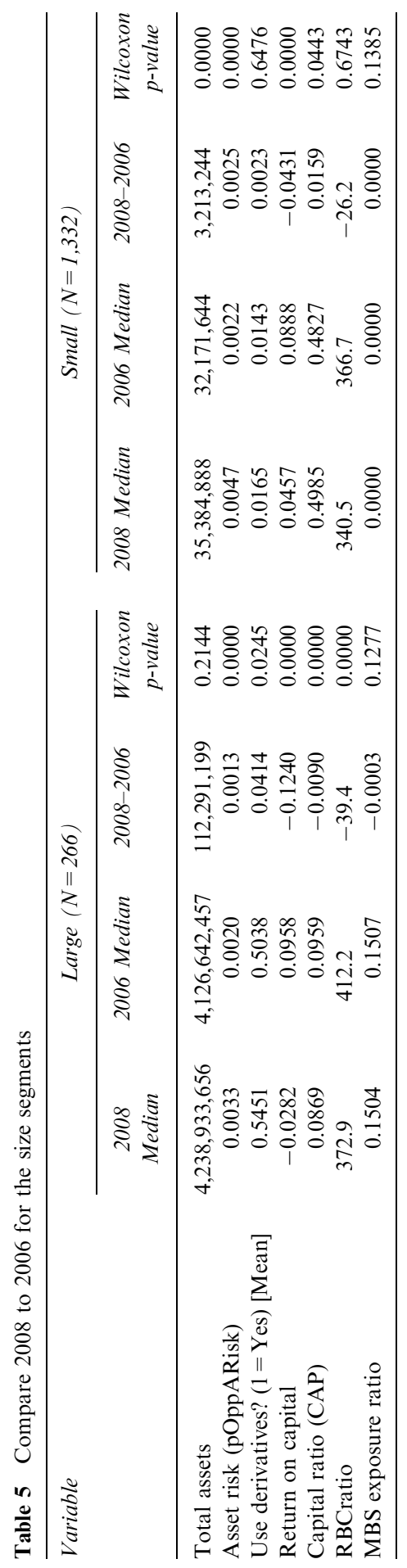




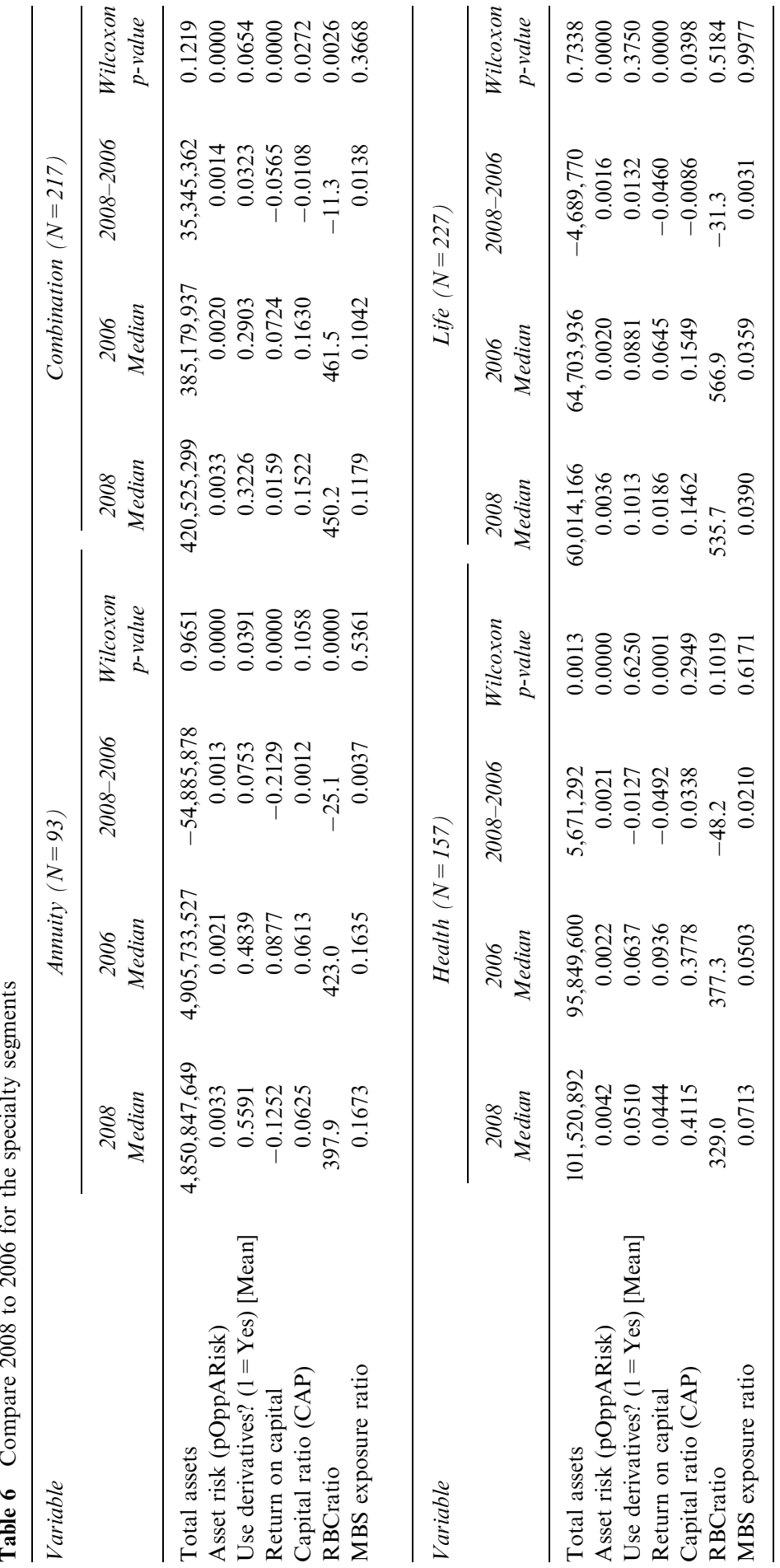




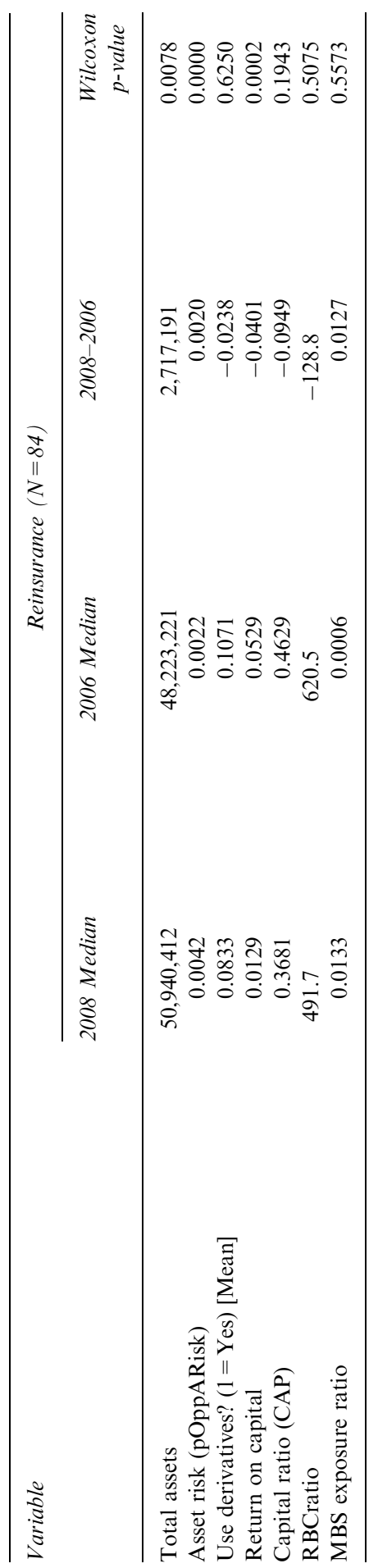




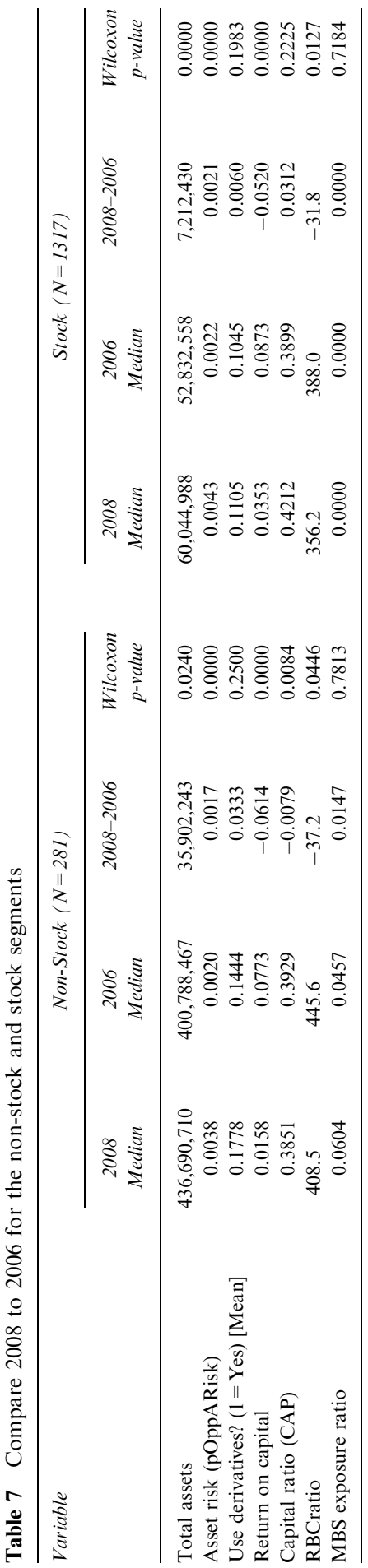


are not shown in the interest of saving space. They are available from the authors. The Wilcoxon signed rank test is used to assess the statistical significance of 2006-2008 changes rather than the usual paired-comparisons $T$-test because of the robustness of the Wilcoxon test to non-normal distributions.

In Table 5, we see that both large and small insurers experienced substantial increases in asset risk in 2008, but the capital ratios moved in opposite directions, with the median large insurer declining and the median small insurer increasing. Still more striking is the difference in capital ratios between large and small insurers. The median small insurers have about five times the capital ratio as the median large insurer. Median profitability (return on capital) of both size segments declined substantiallythat of large insurers much more than that of small ones. ${ }^{43}$ RBC ratios declined somewhat, and MBS exposure remained essentially the same. Derivative use is far more prevalent among large insurers than among small insurers.

In Table 6 we see that all specialty segments experienced increases in asset risk in 2008, as expected during the crisis. Most notable is the gradient in the median capital ratio across the specialties, from about 6 per cent for annuities, to 15 per cent for life and combination, to 40 per cent for health and reinsurance. This ordering of capital ratios is consistent with our interpretation of the TCE ranking of specialties by risk. If annuities are the least risky product, then the annuity segment may hold relatively less capital than other segments, per the finite risk hypothesis. The specialty segments had no significant change in MBS exposure in 2008. Median profitability declined for all segments, and dramatically so for annuity specialists. Median RBC ratios declined for all specialties. There are also substantial differences among specialties in use of derivatives. Derivative use is much more common among annuity (about 50 per cent) and combination types (about 30 per cent) than among health, life and reinsurance specialties (10 per cent or less). There are substantial differences associated with insurance product specialisation.

In Table 7 we see that median stock and non-stock insurers both experienced increases in asset risk in 2008, declines in RBC ratios, little change in MBS exposure and substantial declines in profitability.

\section{Capital and asset risk interrelationship}

As described in the Methodology section, the estimation procedure is two-stage least squares. In the first stage, the two endogenous variables, logCAP and log Asset Risk, are estimated as functions of a common set of predetermined and exogenous predictors. The estimated values (instruments) replace logCAP and log Asset Risk on the left-hand side of Eq. (1) for the stage two regressions. The first stage estimation is merely auxiliary and so results are not presented here. Tables 8 and 9 show the results

\footnotetext{
${ }^{43}$ The decline of the large segment as a whole was much more severe than the median figures suggest. The large segment earned about US\$46 billion in 2006, but lost about US\$44.3 billion in 2008 - a decline in return on capital from 12.3 per cent positive to 12.6 per cent negative. The small segment as an aggregate earned US\$9.2 billion (13.8 per cent) in 2006 and US\$6.4 billion (10.1 per cent) in 2008. Losses among large insurers in 2008 were pervasive. There was also a steep size gradient factor to the deterioration: The larger the insurer, the more its profitability deteriorated.
} 


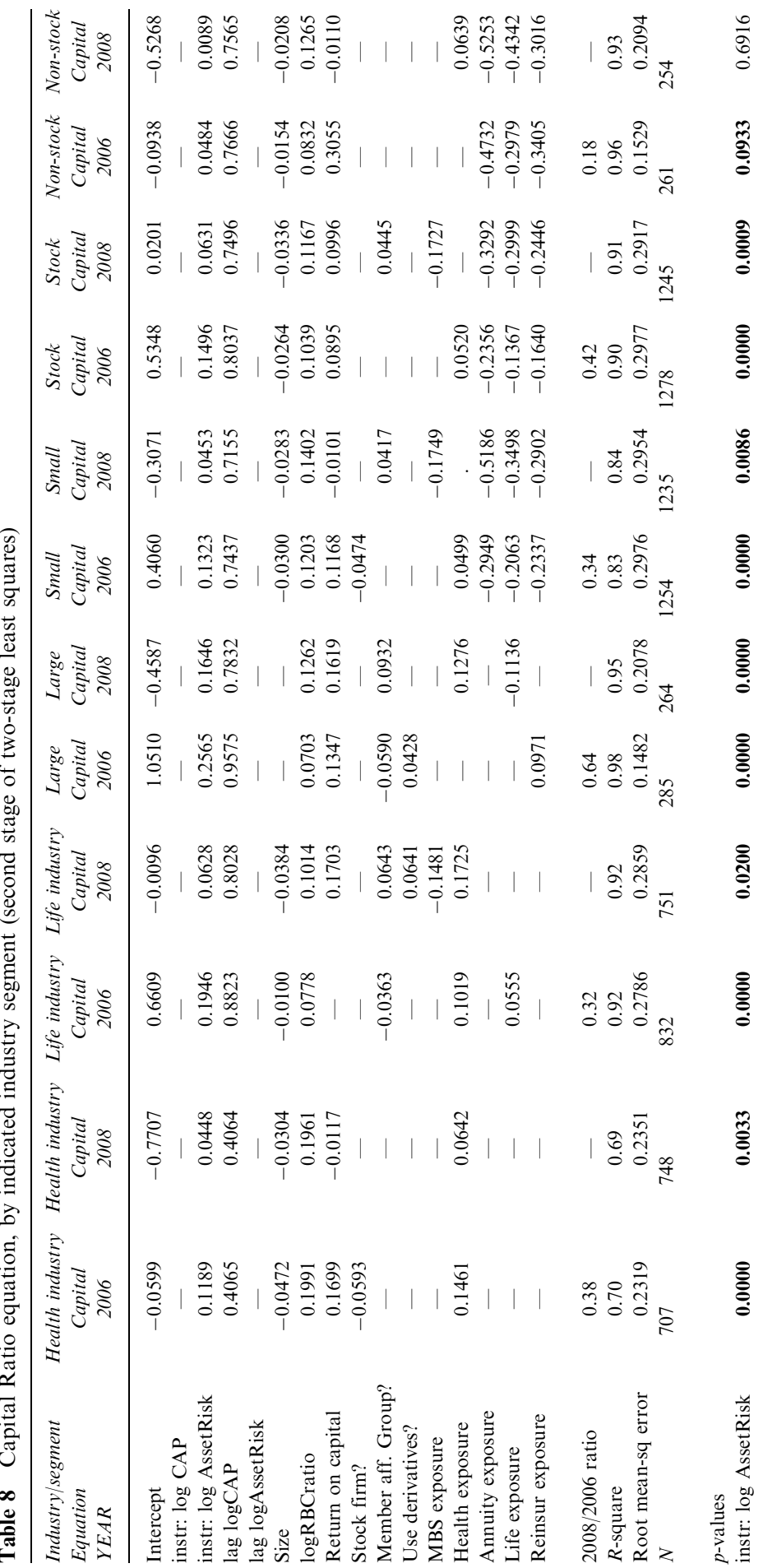




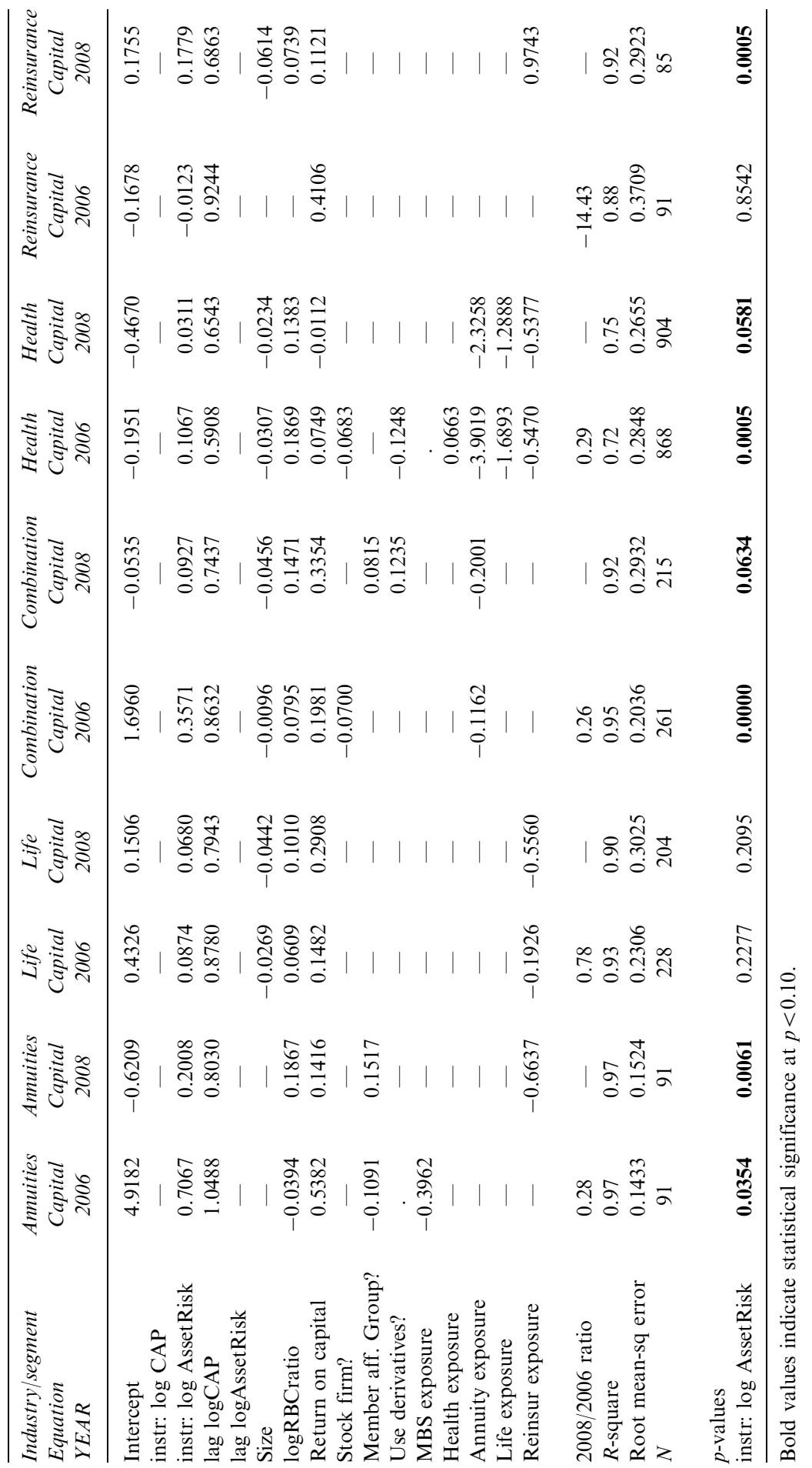




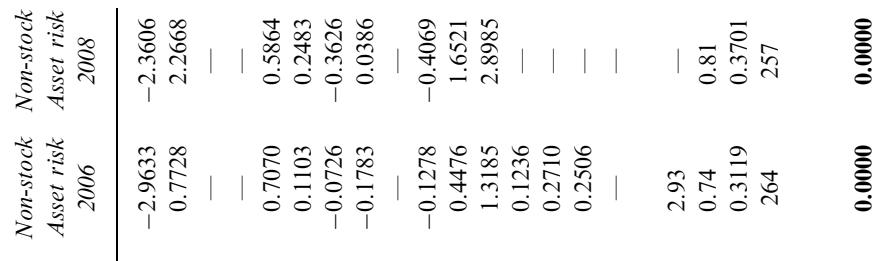

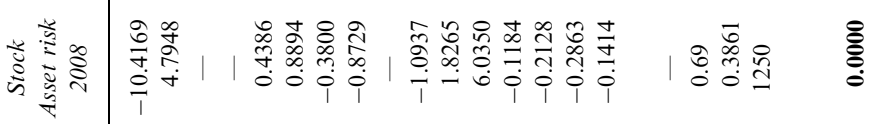

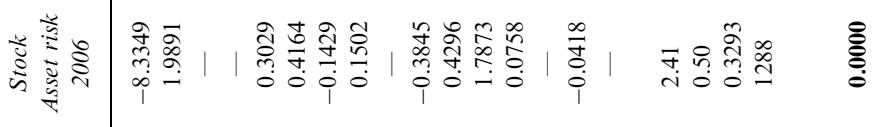

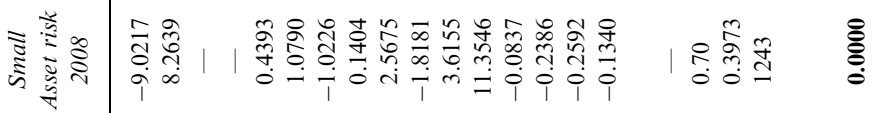

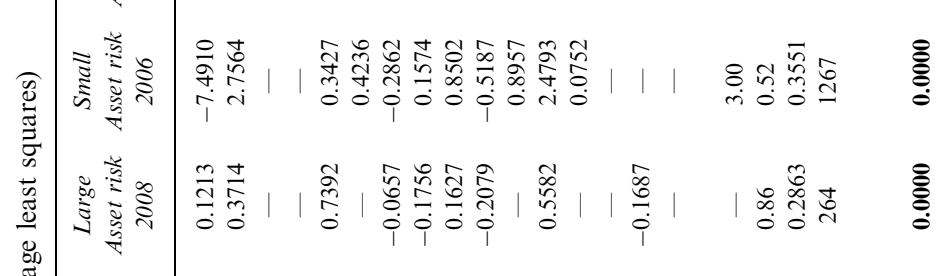

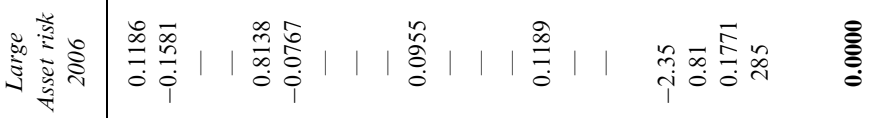

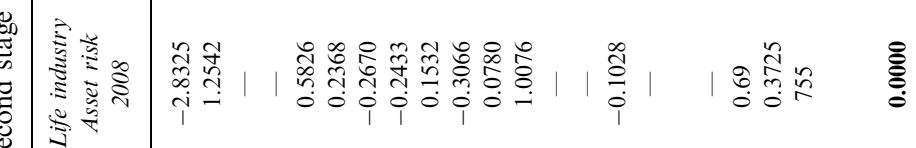

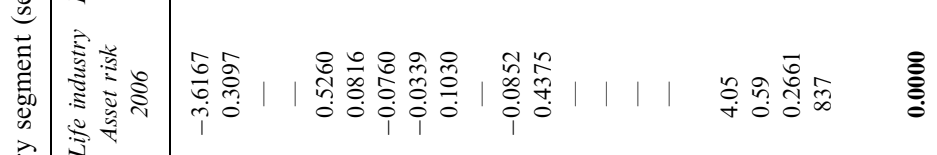

(1)

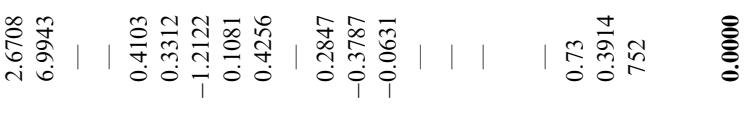

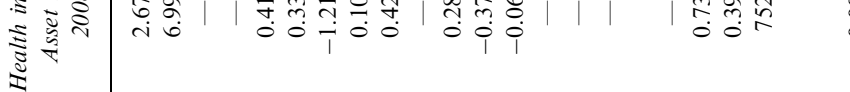

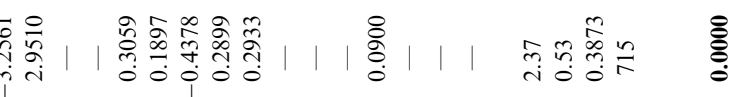

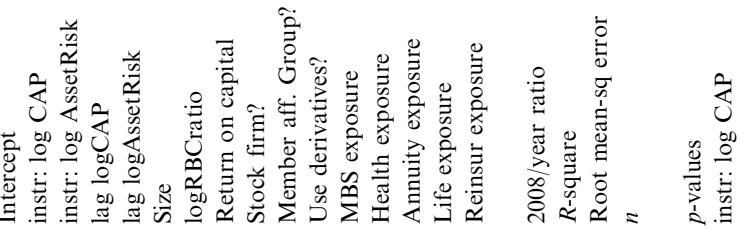




\begin{tabular}{|c|c|c|c|c|}
\hline 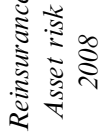 & 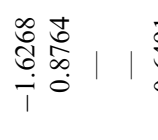 & 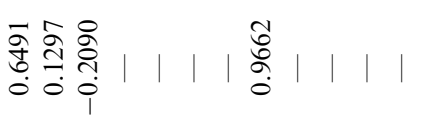 & 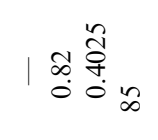 & 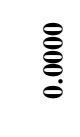 \\
\hline 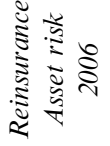 & 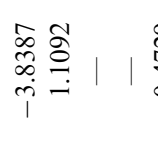 & 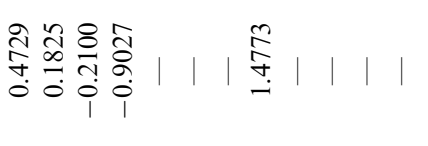 & 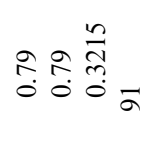 & 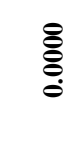 \\
\hline 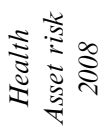 & 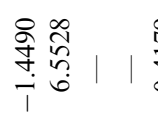 & 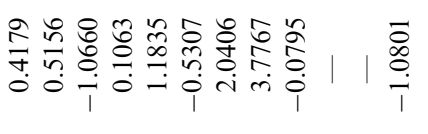 & 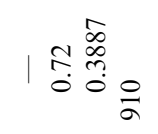 & 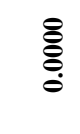 \\
\hline 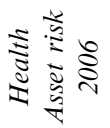 & 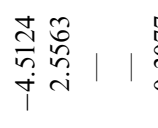 & 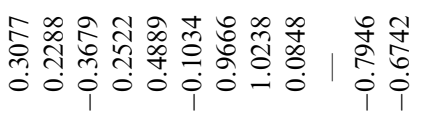 & 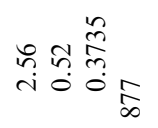 & ڤ్̊̆ \\
\hline 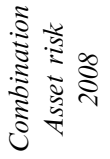 & 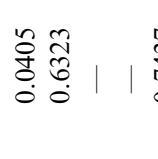 & 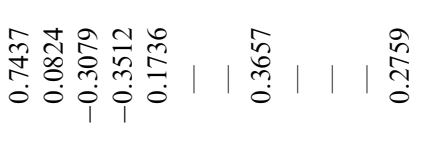 & 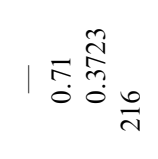 & 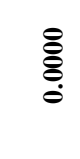 \\
\hline 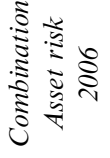 & 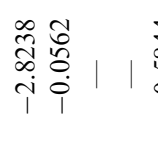 & 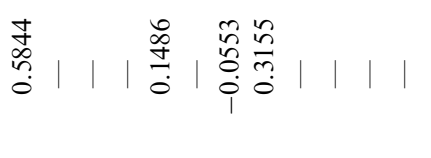 & 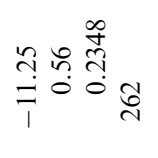 & $\stackrel{\infty}{\mathscr{0}}$ \\
\hline 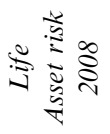 & 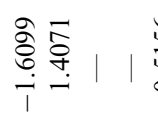 & 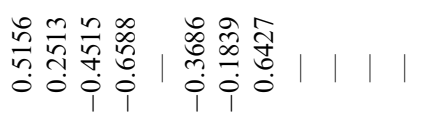 & 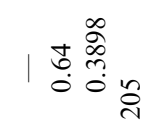 & 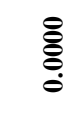 \\
\hline 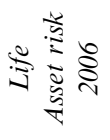 & 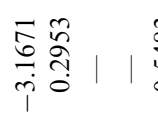 & 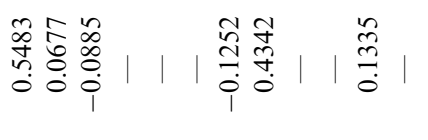 & 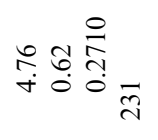 & 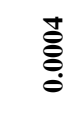 \\
\hline 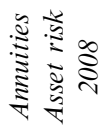 & 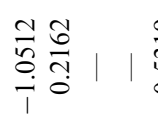 & 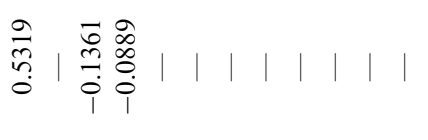 & | iñ & $\stackrel{\oplus}{0}$ \\
\hline 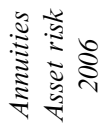 & 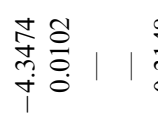 & 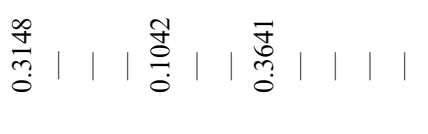 & 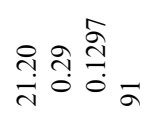 & ஓ̊̊. \\
\hline 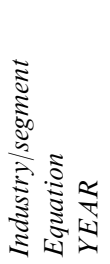 & 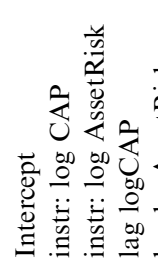 & 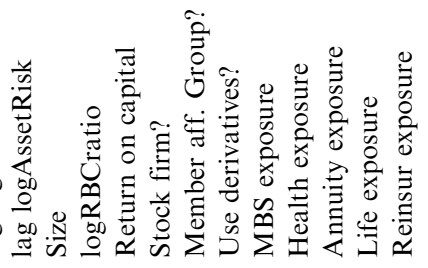 & 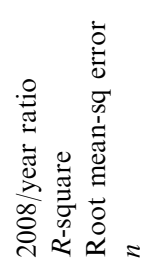 & 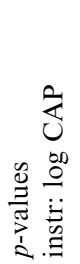 \\
\hline
\end{tabular}


of the stage two estimation for the various segmentations of our study. In order to eliminate insignificant predictors from the model, stepwise regression was used in stage two with default significance levels for retention and elimination $(p=0.15)$. However, both the instrument and the lag of the dependent variable were forced into the model regardless of significance - the instrument because it is the primary predictor of interest, and the lag because of its function in implicitly "mopping up" explanatory power of factors not explicitly listed in the model. To save space, $p$-values are shown only for the instruments, which are the key predictors. However, most of the surviving predictors are highly significant, with $p$-values $<0.001$.

Our primary interest lies in the mutual interrelationship between $\log$ CAP and $\log$ Asset Risk. Table 8 shows the impact of $\log$ Asset Risk on $\log$ CAP, and Table 9 shows the reciprocal impact of $\log$ CAP on $\log$ Asset Risk for the various segmentations. Because both of these variables are in log scale, their coefficients are elasticities of the unlogged variables. ${ }^{44}$ The elasticity of $Y$ with respect to $X$ is the percentage change in $Y$ associated with a 1 per cent increase in $X$. For example, in Table 8 the coefficient of $\log$ Asset Risk in the 2006 model for the Health industry is 0.1189 . This means that a 1 per cent increase in Asset Risk is associated with a 0.1189 per cent increase in the capital ratio, indicating a fairly inelastic relationship. Since the sign is positive, Health insurers in 2006 tended to accumulate more capital in response to an increase in their asset risk. This is consistent with the finite-risk hypothesis explained earlier. In 2008 the coefficient of $\log$ Asset Risk in the same model decreased to 0.0448 , indicating a reduction in the elasticity to a very inelastic relationship. Health insurers in 2008 tended to accumulate even less capital to balance a given percentage increase in asset risk than they did in 2006. Although the sign of the coefficient remains positive, the reduction in its magnitude suggests a movement towards the domain of excessive risk.

Compared with the health industry, the annuities segment displayed a much more pronounced reduction in the elasticity of capital with respect to asset risk as shown in Table 8. The coefficient of log Asset Risk in the 2006 model for the annuities segment is 0.7067 . This means that a 1 per cent increase in Asset Risk is associated with a 0.7067 per cent increase in the capital ratio, indicating a somewhat inelastic relationship. Since the sign is positive, the annuities segment in 2006 tended to accumulate substantial amount of capital in response to an increase in asset risk. This is consistent with the finite-risk hypothesis explained earlier. The elasticity for the median annuity specialist is the largest among the segments. This, too, is consistent with the TCEbased ranking of annuities at the top of types of product risk. In 2008 the coefficient of $\log$ Asset Risk for annuities decreased dramatically to 0.2008 , indicating a major shift towards inelasticity.

An interpretation that is suggested by these empirical findings for the health and annuity segments is that the financial crisis may have impaired the ability of these

\footnotetext{
${ }^{44}$ Actually, the coefficients are partial elasticities, controlling for the other predictors in the model. To see this, consider a generic $\log$ scale model $\log Y=\alpha+\beta \log X+$ other variables. Differentiating partially with respect to $X$, we have $(1 / Y)(\partial Y / \partial X)=\beta(1 / X)$. Solving, we have $\beta=(\partial Y / Y) /(\partial X / X)$. This formula shows that for a given small change $\partial X$ in $X$, the coefficient $\beta$ is the percentage change in $Y$ divided by the percentage change in $X$.
} 
insurers to maintain their pre-crisis relationship between capital and asset risks. As shown in Tables 5, 6 and 7, asset risk (pOppARisk) doubled for the median health insurer and increased by half for the median annuity specialist from 2006 to 2008 . Yet capital ratios barely changed. The elasticity of capital with respect to asset risk slid towards inelasticity and excessive risk ("go for broke"), especially for annuity specialists, but remained within the realm of finite risk (positive elasticity). Consistent with these results is the possibility that these insurers had difficulty raising capital during the crisis, and also the more disturbing possibility that insurers were nudged towards excessively risky behaviours by aggravating external conditions. Our data do not distinguish these possibilities.

As we generated the models for the other segments, we were struck by the consistency of the movement towards excessive risk in 2008, as shown by the elasticities of capital with respect to asset risk. To facilitate identification of the trend towards excessive risk, we computed the ratio of the elasticities for the two years $(2008 \div 2006)$ and included the ratio in Tables 8 and 9. For example, the 2008/2006 ratio of capital elasticities for large insurers is 0.64 and for small insurers is 0.34 . Large insurers had double the capital elasticity of small insurers in 2006, and the capital elasticity of each declined by about the same absolute amount in 2008. This reduction left the small insurers with almost no elasticity - similar to the situation for health insurers. For all segments, the ratio of statistically significant log Asset Risk coefficients (2008 capital elasticity $\div 2006$ capital elasticity) is less than one, but positive (see Table 8 ). Thus the interplay between capital and asset risk uniformly lost flexibility in 2008 but the segments did not switch into the excessive risk paradigm despite the systemic risks of the financial crisis.

Table 9 shows the results for Eq. (2), the structural model for asset risk. In this model, the capital ratio is a predictor. We expect the coefficients of logCAP (the partial elasticity of asset risk with respect to the capital ratio) to show relationships between asset risk and capital that are reciprocal to those shown in Table 8 . Where the capital elasticities decreased from 2006 to 2008 in Table 8, we expect the asset risk elasticities to increase in Table 9. That is exactly what we find, except for the reinsurance segment. (The combination and large segments have negative 2008/2006 ratios because their 2006 elasticities are negative. But both segments increased from negative to larger positive elasticities, which is consistent with the observed trend.) For example, in the Health industry model for 2006, the coefficient of $\log$ CAP is 2.5563 and for 2008 it is 6.5528 , with a $2008 / 2006$ ratio of 2.56 . This indicates that a 1 per cent increase in the capital ratio is associated with a 2.5563 per cent increase in Asset Risk in 2006, but a 6.5528 per cent increase in Asset Risk in 2008. The same percentage increase in capital had to cover much more Asset Risk in 2008 than in 2006. The annuities segment $\log$ CAP coefficient (0.0102) is not significant in 2006. However, if we interpret the annuities segment anyway, we would say that a 1 per cent increase in the capital ratio is associated with a very low per cent increase in Asset Risk in 2006, but a much greater per cent increase (0.2162) in Asset Risk in 2008. The ratio $(2008 \div 2006)$ is 21.20 , which is reciprocally consistent with the corresponding result in the CAP model above.

Like the structural equation for capital, the structural equation for asset risk is consistent with a movement towards excessive risk by all segments but reinsurance. 
Loosely put, this finding says that insurers may have lost some ability, or perhaps lost some desire, to maintain their pre-crisis balance between capital and asset risk. The annuities segment was relatively more adversely impacted than other segments.

Comments on other predictors in the models: The coefficient of Size is always negative in the $\log$ CAP models and is always positive in the log Asset Risk models (except for the large sector in 2006). That is, larger size within most segments is associated with lower capital ratio and with higher asset risk. So larger firms accept relatively larger asset risks, without balancing those risks with increased capital, as smaller firms do. This accords with expectation if size is considered a risk-neutralising trait in itself. It also accords with the notion of "too-big-to-fail".

The results for the operational risks are in line with expectations. The coefficient of $\log$ RBCratio is positive in all segments in the logCAP model (except for annuities in 2006) and negative in all segments in the log Asset Risk model. Thus, as insurers approach the level of regulatory scrutiny (lower RBCratio), their capital ratios decrease and Asset Risk increases - which is consistent with attracting regulatory scrutiny.

On the whole, increases in MBS exposure are associated with decreases in capital and with increases in Asset Risk, as though in pre-crisis times MBS were treated as high quality investments - a finding consistent with Baranoff and Sager. ${ }^{26}$ The contribution of return on capital to the asset risk equation is not consistent among the segments.

Table 10 summarises the above discussion with regard to the implications of the capital equation (Table 8 ) for our expectations that were presented earlier in Table 1. Table 10 follows the same format as Table 1, but adds results rows below the expectation rows. In general, the estimated capital model supports our expectations. A similar table of expectations and results could be shown for the asset risk equation. However, such a table would be mostly redundant since we have seen that the asset risk model reflects the capital-asset risk interrelationship in a consistently reciprocal manner to that of the capital model. Therefore we omit that table.

\section{Summary}

The period 2006-2008 offers an experimental laboratory for the study of industries under crisis. The financial sector (including insurance) is viewed as the sector most responsible for the crisis and also most affected by the crisis. Although banks have drawn most of the media and remedial legislative attention, insurers were included within the purview of the "Dodd-Frank Wall Street Reform and Consumer Protection Act", which created the FIO as a new layer of insurance regulation. Nearly simultaneously, health care reform (PPACA) was enacted, with the potential for significant impact on health insurers. The need is evident to understand how the various sectors of the financial industry reacted during the crisis and also how reforms might be expected to impact the industry.

In this study, we explore intra-industry variations in the interplay between capital and asset risks in a large part of the insurance industry. We partition the life and health insurance industries into subsector segments by predominant business focus: 
Table 10 Expectations and results for the effects of product and asset risks on capital, based upon business strategy and finite risk hypotheses

\begin{tabular}{|c|c|c|c|c|c|c|c|c|}
\hline & \multicolumn{2}{|c|}{$\begin{array}{l}\text { Annuity } \\
\text { segment }\end{array}$} & \multicolumn{2}{|c|}{$\begin{array}{c}\text { Life } \\
\text { segment }\end{array}$} & \multicolumn{2}{|c|}{$\begin{array}{l}\text { Health } \\
\text { segment }\end{array}$} & \multicolumn{2}{|c|}{$\begin{array}{l}\text { Reinsurance } \\
\text { segment }\end{array}$} \\
\hline & 2006 & 2008 & 2006 & 2008 & 2006 & 2008 & 2006 & 2008 \\
\hline \multicolumn{9}{|c|}{ Product risk coefficient } \\
\hline $\begin{array}{l}\text { Expectation: } \\
\text { Result: }\end{array}$ & $\begin{array}{c}\text { Low }+ \\
\text { NS }\end{array}$ & $\begin{array}{c}\text { Low }+ \\
\text { NS }\end{array}$ & $\begin{array}{l}\text { Medium }+ \\
\text { NS }\end{array}$ & $\begin{array}{l}\text { Medium }+ \\
\text { NS }\end{array}$ & $\begin{array}{c}\text { High }+ \\
+\end{array}$ & $\begin{array}{c}\text { High }+ \\
\text { NS }\end{array}$ & $\begin{array}{l}\text { High }+ \\
\text { NS }\end{array}$ & $\begin{array}{c}\text { High }+ \\
+\end{array}$ \\
\hline \multicolumn{9}{|c|}{ Asset risk coefficient } \\
\hline \multirow[t]{3}{*}{$\begin{array}{l}\text { Expectation: } \\
\text { Result: }\end{array}$} & $\begin{array}{l}\text { High + } \\
\text { High }+\end{array}$ & $\begin{array}{c}\text { Low }+ \text { or }- \\
\text { Low }+\end{array}$ & $\begin{array}{c}\text { Medium }+ \\
\text { NS }\end{array}$ & $\begin{array}{c}\text { Low }+ \text { or }- \\
\text { NS }\end{array}$ & $\begin{array}{l}\text { Low }+ \\
\text { Low }+\end{array}$ & $\begin{array}{c}\text { Low }+ \text { or }- \\
\text { Low }+\end{array}$ & $\begin{array}{c}\text { Low }+ \\
\text { NS }\end{array}$ & $\begin{array}{c}\text { Low }+ \text { or }- \\
\text { Low }+\end{array}$ \\
\hline & \multicolumn{2}{|c|}{$\begin{array}{c}\text { Small } \\
\text { segment }\end{array}$} & \multicolumn{2}{|c|}{$\begin{array}{c}\text { Large } \\
\text { segment }\end{array}$} & \multicolumn{2}{|c|}{$\begin{array}{c}\text { Stock } \\
\text { segment }\end{array}$} & \multicolumn{2}{|c|}{$\begin{array}{c}\text { Non-stock } \\
\text { segment }\end{array}$} \\
\hline & 2006 & 2008 & 2006 & 2008 & 2006 & 2008 & 2006 & 2008 \\
\hline \multicolumn{9}{|c|}{ Product risk coefficient } \\
\hline Expectation: ${ }^{a}$ & $\mathrm{~N} / \mathrm{A}$ & $\mathrm{N} / \mathrm{A}$ & $\mathrm{N} / \mathrm{A}$ & $\mathrm{N} / \mathrm{A}$ & $\mathrm{N} / \mathrm{A}$ & $\mathrm{N} / \mathrm{A}$ & $\mathrm{N} / \mathrm{A}$ & $\mathrm{N} / \mathrm{A}$ \\
\hline Result: $^{\mathrm{a}}$ & $\mathrm{N} / \mathrm{A}$ & $\mathrm{N} / \mathrm{A}$ & $\mathrm{N} / \mathrm{A}$ & $\mathrm{N} / \mathrm{A}$ & $\mathrm{N} / \mathrm{A}$ & $\mathrm{N} / \mathrm{A}$ & $\mathrm{N} / \mathrm{A}$ & $\mathrm{N} / \mathrm{A}$ \\
\hline \multicolumn{9}{|c|}{ Asset risk coefficient } \\
\hline Expectation: & + & Low + or - & + & Low + or - & + & Low + or - & + & Low + or - \\
\hline Result: & + & Low + & + & Low + & + & Low + & NS & Low + \\
\hline
\end{tabular}

${ }^{\mathrm{a}}$ Mixed products.

Table shows expectations and results for coefficients in the capital equation by industry segment (see Table 8 for results).

health and accident, life, annuity, reinsurance, and combination segments. In addition, we examine partitions based upon other criteria, such as size and organisational form.

We conduct the study within the context of the four major categories of insurers' enterprise risks: asset, financial, product, and operational. We argue that product and operational risks remain fairly stable over time for most insurers. Thus, the product and operational risks were not as much affected by the systemic risks of the crisis as were asset and financial risks. We therefore focus on the interaction between the asset risk and financial risk. More specifically, we examine the elasticity of insurer capital during and immediately preceding the crisis, especially in relation to asset risk, but also within the context of the other major risks to which insurers are subject. We measure asset risk by a volatility-of-returns index, and financial risk by the capital ratio (capital structure), corresponding to leverage for non-financial firms, and use simultaneous equation models with capital and asset risk as endogenous and other enterprise risks and controls as exogenous.

We repeat the analysis for each segment and find that the most notable differences are between the health and annuities specialty segments. We find that during the crisis all segments moved uniformly towards lower capital elasticities, but the impact in the annuities segment is the most pronounced. When the capital/risk relationship becomes inelastic, insurers may lose their ability to increase capital in response to increased asset risk, or even may move into the excessive risk mode from the finite-risk mode. 
The partial elasticity of the health segment was very low in 2006 and declined to almost no elasticity in 2008. Findings such as these, which not only point out industry-wide sensitivities to risk, but also differentiate higher and lower sensitivities within the industries, may aid the newly created FIO in its mission to understand these important industries better, and as regulators strive to prevent or ameliorate potential future crises.

\section{References}

Babbel, D.F. and Merrill, C. (2005) 'Real and illusory value creation by insurance companies', The Journal of Risk and Insurance 72(1): 1-21.

Baranoff, E.G. (2011) 'An Analysis of the AIG Case-Understanding Systemic Risk and its Relation to Insurance', The Geneva Association, from www.genevaassociation.org.

Baranoff, E.G., Papadopoulos, S. and Sager, T.W. (2007) 'Capital and risk revisited: A structural equation model approach for life insurers', The Journal of Risk and Insurance 74(3): 653-681.

Baranoff, E.G. and Sager, T.W. (2002) 'The relations among asset risk, product risk, and capital in the life insurance industry', Journal of Banking and Finance 26(6): 1181-1197.

Baranoff, E.G. and Sager, T.W. (2003) 'The relations among organizational and distribution forms and capital and asset risk structures in the life insurance industry', The Journal of Risk and Insurance 70(3): 375-400.

Baranoff, E.G. and Sager, T.W. (2009) 'The impact of mortgage-backed securities on capital requirements of life insurers in the financial crisis of 2007-2008', The Geneva Papers on Risk and Insurance-Issues and Practice 34(1): 100-118.

Baranoff, E.G., Sager, T.W. and Witt, R.C. (1999) 'Industry segmentation and predictor motifs for solvency analysis of the life/health insurance industry', The Journal of Risk and Insurance 66(6): 99-123.

Barclay, M.J. and Morellec, E. (2006) 'On the debt capacity of growth options', Journal of Business 79(1): 37-60.

Berger, A.N. (1995) 'The relationship between capital and earnings in banking', Journal of Money, Credit, and Banking 27(2): 432-456.

Berger, A.N. and Bonaccorsi di Patti, E. (2006) 'Capital structure and firm performance: A new approach to testing agency theory and an application to the banking industry', Journal of Banking and Finance 30(4): 1065-1102.

Berger, A.N., Herring, R.J. and Szego, G.P. (1995) 'The role of capital in financial institutions', Journal of Banking and Finance 19(3-4): 393-430.

Coase, R.H. (1937) 'The nature of the firm', Economica, 4(16): 386-405, [Reprint in Industrial Organization by Williamson, O. E. (1990)].

Cummins, J.D. (1988) 'Risk-based premiums for insurance guaranty funds', Journal of Finance 43(4): 823-839.

Cummins, J.D. and Sommer, D.W. (1996) 'Capital and risk in property-liability insurance markets', Journal of Banking and Finance 20(6): 1069-1092.

Downs, D.H. and Sommer, D.W. (1999) 'Monitoring, ownership, and risk-taking: The impact of guaranty funds', The Journal of Risk and Insurance 66: 477-497.

Faulkender, M.W. and Petersen, M.A. (2006) 'Does the source of capital affect capital structure?' Review of Financial Studies 19(1): 45-79.

Flannery, M.J. and Rangan, K.P. (2006) 'Partial adjustment toward target capital structures', Journal of Financial Economics 79(3): 469-506.

Gleason, J.T. (2000) Risk: The New Management Imperative in Finance, Princeton, NJ: Bloomberg Press.

Graham, J.R. and Harvey, C.R. (2001) 'The theory and practice of corporate finance: Evidence from the field', Journal of Financial Economics 60(2-3): 187-243.

Harris, M. and Raviv, A. (1991) 'The theory of capital structure', Journal of Finance 46(1): 297-355.

Harvey, C.R., Lins, K.V. and Roper, A.H. (2004) 'The effect of capital structure when expected agency costs are extreme', Journal of Financial Economics 74(1): 3-30.

Hovakimian, A., Hovakimian, G. and Tehranian, H. (2004) 'Determinants of target capital structure: The case of dual debt and equity issues', Journal of Financial Economics 71(3): 517-540.

Hovakimian, A., Opler, T. and Titman, S. (2001) 'The debt-equity choice', Journal of Financial and Quantitative Analysis 36(1): 1-36. 
Jensen, M. and Meckling, W. (1976) 'Theory of the firm: Managerial behavior, agency costs and ownership structure', Journal of Financial Economics 3(4): 305-360.

Kayhan, A. and Titman, S. (2007) 'Firms' histories and their capital structures', Journal of Financial Economics 83(1): 1-32.

Leary, M.T. and Roberts, M.R. (2005) 'Do firms rebalance their capital structures?' The Journal of Finance 60(6): 2575-2619.

MacKay, P. and Phillips, G.M. (2005) 'How does industry affect firm financial structure?' The Review of Financial Studies 18(4): 1433-1466.

Mayers, D. and Smith, C.W. (1981) 'Contractual provisions, organizational structure, and conflict control in insurance markets', The Journal of Business 54(3): 407-434.

Mayers, D. and Smith, C.W. (1986) 'Ownership structure and control: The mutualization of stock life insurance companies', Journal of Financial Economics 16(1): 73-98.

Mayers, D. and Smith, C.W. (1988) 'Ownership structure across lines of property-casualty insurance', Journal of Law and Economics 31: 351-378.

Mayers, D. and Smith, C.W. (1994) 'Managerial discretion, regulation, and stock insurer ownership structure', The Journal of Risk and Insurance 61(4): 638-655.

Miao, J. (2005) 'Optimal capital structure and industry dynamics', The Journal of Finance 60(6): 2621-2659.

Regan, L. and Tzeng, L.Y. (1999) 'Organizational form in the property-liability insurance industry', The Journal of Risk and Insurance 66(2): 253-273.

Santomero, A.M. and Babbel, D.F. (1997) 'Financial risk management by insurer: An analysis of the process', The Journal of Risk and Insurance 64(2): 231-270.

Shrieves, R. and Dahl, D. (1992) 'The relationship between risk and capital in commercial banks', Journal of Banking and Finance 16(2): 439-457.

Shyam-Sunder, L. and Myers, S.C. (1999) 'Testing static tradeoff against pecking order models of capital structure', Journal of Financial Economics 51(2): 219-244.

Titman, S. and Wessels, R. (1988) 'The determinants of capital structure choice', The Journal of Finance 43(1): 1-19.

Williamson, O.E. (1985) The Economic Institution of Capitalism, New York: The Free Press, A Division of Macmillan, Inc.

Williamson, O.E. (1988) ‘Corporate finance and corporate governance', The Journal of Finance 43(3): 567-591.

\section{About the Authors}

Etti Baranoff is an Associate Professor of Insurance and Finance at Virginia Commonwealth University in Richmond, VA, since 1995. Along with her faculty position, she was appointed as a Research Director for Insurance and Finance by the International Association for the Study of Insurance Economics (The Geneva Association) in October 2010. Prior to her academic career, she was a Texas insurance regulator for 12 years with specialty in rate regulation, solvency studies and modeling and legislative issues. She has a $\mathrm{PhD}$ in finance, insurance and statistics from the University of Texas, Austin, in 1993. Her BA in economics and statistics and her teaching certificate are from the University of Tel Aviv, Israel. Her career also includes experience with a life insurer, a Texas public risk pool and consulting.

Thomas W. Sager has a $\mathrm{PhD}$ degree in statistics from the University of Iowa. He has been Professor of Statistics at Stanford University and the University of Texas. His research interests have included the mathematical theory of statistics and the application of statistics to environmental studies and insurance companies. He has also consulted extensively for insurance and re-insurance companies, law firms, government agencies, large and small corporations and consulting firms. 